\title{
Educational Exchange as a Cold War Weapon: American Influence on Danish Journalists after World War II
}

\section{Anders Bo Rasmussen}

University of Southern Denmark, Odense

\begin{abstract}
American President Harry S. Truman called the Cold War a "struggle for the minds of men," and assigned journalists an important role in the conflict. The American administration's strategy was to influence young people and opinion leaders in countries deemed important during the Cold War in the hope that their views would trickle down to the broader population. This article analyzes transnational flows of people and knowledge between the United States and Denmark after World War II. Through an examination of archival material, the study finds that the U.S. Department of State, via the American Embassy in Copenhagen, consciously attempted to shape Danish journalists' view of America directly and indirectly. The article finds that American officials were very skilled at picking future opinion and media leaders for educational exchange and thereby provided them with a deeper understanding of $U$. S. affairs.
\end{abstract}

Keywords: Americanization-transnationalization—Cold War-cultural diplomacy—journalism practice-Fulbright.

\section{Introduction}

Addressing the American Society of Newspaper Editors in 1950, President Harry S. Truman made clear that the Cold War was more than a struggle over military strategy and economic ideology. The fight against the Soviet 
Union, Truman said, was above all a struggle "for the minds of men." ${ }^{\text {Ac- }}$ cording to Truman, gaining the cultural upper hand in the ideological fight against communism was crucial for the United States, and in this struggle, journalists-both inside and outside the United States-were thought to play a key role.

According to American diplomats, because of its "island possessions," meaning Greenland and the Faroe Islands, Denmark was considered "vital to the United States security" after World War II. ${ }^{2}$ Greenland especially was a recurring theme in American officials' reports back to Department of State. Ambassador John Gunther Dean summed up Greenland's importance when he in 1976 noted that "[t]here are several factors which make US interests in Denmark greater than would ordinarily be expected in a country of its size," and added that these interests had been relatively unchanged for decades,

[They] stem basically from a similarity in national views rooted in Denmark's long democratic tradition, its western value system, and its strategic location. Denmark's position at the entrance to the Baltic and its sovereignty over Greenland and the Faroes, both important to the defense of the North Atlantic, make its role in the NATO alliance a key one. ${ }^{3}$

Dean's comments underlined the importance placed by the Americans on Denmark's participation in NATO. The American air bases on Greenland meant that Denmark was seen as a small, but not wholly unimportant, piece in the puzzle to secure an upperhand in the Cold War. Therefore, influencing Danish media personnel took on added importance as American officials believed that media personnel sympathetic to the United States would result in "good coverage on all aspects of American life," as Public Affairs Officer William G. Roll wrote in a confidential report from $1950 .{ }^{4}$ Danish

1 Richard Pells, Not Like Us: How Europeans Have Loved, Hated, and Transformed American Culture since World War II (New York: Basic Books, 1997), p. 65. Pells writes: "At the moment, Truman, warned, the Communists were winning the battle for those minds by subjecting the United States to a 'constant stream of slander and vilification.' But the American people would eventually prevail if they made themselves 'heard round the world in a great campaign of truth'."

2 Paul Villaume, Allieret Med Forbehold: Danmark, Nato Og Den Kolde Krig [Allied with Reservations: Denmark, Nato and the Cold War] (Copenhagen: Eirene, 1995), pp. 123-124.

3 John Gunther Dean, "Annual Policy Assessment," (http://aad.archives.gov/aad/createpdf?rid= 84211\&dt=2082\&dl=1345. April 29, 1976). Downloaded November 10, 2010.

4 William G. Roll, "USIE Country Papers," (National Archives. RG 59. Department of State. Decimal file. 1950-1954. From 511.59/12-650 to 511.59/12-2950. Box 2422. May 2, 1950), p. 4. 
journalists were seen as inhabiting the top of an information pyramid, from where views and values would trickle down to the larger population.

So after Denmark's entry into NATO in 1949, educational exchange was identified as a key cultural diplomatic component. Roll underscored this belief in his report to the Department of State on May 2, 1950, from the American Embassy in Copenhagen. The report stated that "in the long run the exchange of persons would be our most effective approach to the Danes."

American officials such as Roll assumed that "Americanizing" Danish journalists by introducing them to American values, norms, and beliefs through educational exchange would create a more positive image of American society and culture which again would assure continued broad public support for participation in NATO. ${ }^{6}$

Based on archival research in Denmark and the United States the current article traces the educational exchange between the two countries by examining the United States Department of State reports as well as the Danish journalists' own assessments. It shows how educational exchange created a more nuanced and positive view of the United States for the majority of the leading Danish journalists who were selected by the officers at the American Embassy in Copenhagen. Additionally, building on previous research, the article confirms that the American Embassy worked very consciously to shape Danish journalists' view of the United States through direct and indirect communication. ${ }^{7}$ The arguments may be relevant in a broader European context as well. As Alexander Stephan has shown in his edited volume The Americanization of Europe, after World War II there were many similarities between the development in European countries and their experiences of Americanization. ${ }^{8}$

6 Martin Kryhl Jensen, "En Krig På Værdier-Mål Og Midler I Det Amerikanske Kulturdiplomati [A War on Values: Means and Ends in the American Cultural Diplomacy]," in Fodnoter, ed. Bent Jensen (Copenhagen: Center for Koldkrigsforskning, 2009), p. 10.

7 Richard Pells, Not Like Us: How Europeans Have Loved, Hated, and Transformed American Culture since World War II. See also Nils Arne Sørensen and Klaus Petersen, "Ameri-Danes and Pro-American AntiAmericans," in The Americanization of Europe: Culture, Diplomacy, and Anti-Americanism after 1945, ed. Alexander Stephan (New York: Berghahn Books, 2006), as well as Paul Villaume, Allieret Med Forbehold: Danmark, Nato Og Den Kolde Krig [Allied with Reservations: Denmark, Nato and the Cold War].

8 Alexander Stephan, "Cold War Alliances and the Emergence of Transatlantic Competition: An Introduction," in The Americanization of Europe: Culture, Diplomacy, and Anti-Americanism after 1945, ed. Alexander Stephan (New York: Berghahn Books, 2006). 


\section{Research on Americanization}

President Truman's depiction of the Cold War as an intellectual struggle addresses the core of symbolic Americanization, meaning the American impact in the cultural realm - and here defined as processes in which political and cultural influences "emanating from America or Americans impinge on values, norms, belief systems," and/or "practices of non-Americans.",

The definition is attributed to Dutch scholar Mel Van Elteren, who theoretically grounds his work on Americanization in a hybrid position between the concept of cultural imperialism-meaning American influence that the receiving country has no ability to resist; and what Van Elteren terms "extreme social constructionism" - an approach in which the very existence of a "real" America is called into question. Van Elteren understands Americanization as a middle ground where receiving nations' agency is taken into account, but also recognizes that America is a "stubborn, historical-societal reality," with tangible political and cultural influence on other nations. ${ }^{10}$

The study of Americanization can roughly be divided into three phases, here designated as cultural imperialism, assimilation, and power asymmetry. The current study follows in the tradition of research emphasizing power asymmetry, which acknowledges receiving countries' and individual agents' ability to adapt to impulses coming from the United States as opposed to being powerless in the Americanization process.

The United States has since 1945 held an unrivaled global position of power militarily and economically and consequently the relationship that Denmark entered into with the United States after the end of World War II was one of asymmetrical power. Despite knowledge that Denmark would be abandoned in case of an attack by the Soviet Union on the NATO countries, Danish politicians, like Julius Bomholt from the Social Democrats, nevertheless felt that the nation had to make a choice between east and west, as a Scandinavian defense agreement failed to materialize, and the Danes somewhat reluctantly then chose to join the Atlantic Pact. ${ }^{11}$

Yet, the American need for access to Greenland's air bases on Greenland

9 Mel Van Elteren, "Rethinking Americanization Abroad: Toward a Critical Alternative to Prevailing Paradigms," The Journal of American Culture 29, no. 3 (2006), pp. 345-354.

10 Americanism and Americanization: A Critical History of Domestic and Global Influence (Jefferson, North Carolina: McFarland \& Company, Inc., Publishers, 2006). Page 125-131.

11 Paul Villaume, Allieret Med Forbehold: Danmark, Nato Og Den Kolde Krig [Allied with Reservations: Denmark, Nato and the Cold War], pp. 354-357. 
ensured Danish politicians a powerful bargaining chip. As Paul Villaume has shown, Danish politicians in the 1950 s were strongly encouraged by American officials to spend more on defense in exchange for the economic support provided through the Marshall plan, but Danish politicians wanted to spend the money on domestic programs. Consequently, the Americans in 1955 concluded that the Danish government had not invested enough in the country's military and as a result considered cutting economic aid. In the end, however, the United States decided against decreasing Danish assistance partly because it could "weaken USA's position in Greenland." 12

The relationship between Denmark and the United States therefore does not resemble the "cultural imperialist" interpretation offered by Herbert Schiller, among others, where America dominates other nations who are "attracted, pressured, forced, and sometimes bribed into shaping social institutions to correspond to, or even promote, the values and structures of the dominating center of the system." ${ }^{13}$

Nor does this understanding of asymmetric power relationships fit with a more assimilationist view as promoted by Richard Pells, among others, wherein Europe has had as much influence on the United States after World War II as the United States has had on Europe. ${ }^{14}$

As Danish historian Nils Arne Sørensen has noted, Americanization and Europeanization do not hold equal weight. The United States more often than not sets the agenda in relation to European powers. ${ }^{15}$

Van Elteren situates his work in the tradition of power asymmetry by emphasizing the receiving country's ability to resist American influence while acknowledging the structural differences between the United States and Europe. Thus, the overt American attempts to shape Danish journalists' views of the United States, which are the focus of the present paper, can be fruit-

12 Ibid., pp. 348-354.

13 Herbert I. Schiller, Communication and Cultural Domination (New York: International Arts and Sciences Press, 1976). Page 9. See also Pierre Bourdieu, On Television, trans. Priscilla Parkhurst Ferguson (New York: The New Press, 1998), pp. 40-42.

14 Richard Kuisel, "Debating Americanization: The Case of France," in Global America? The Cultural Consequences of Globalization, ed. Ulrich Beck, Natan Sznaider, and Rainer Winter (Liverpool: Liverpool University Press, 2003), p. 98. See also Richard Pells, Not Like Us: How Europeans Have Loved, Hated, and Transformed American Culture since World War II, pp. 27, 50-51, 188 and 344.

15 Nils Arne Sørensen, "Kulturmøder, Selvkolonisering Og Imperialisme Om Usamerikaniseringen Af Europa [Cultural Encounters, Self-Colonialization and Imperialism: About Usamericanization of Europe]," in Transnationale Historier, ed. Anne Magnussen Sissel Bjerrum Fossat, Klaus Petersen, Nils Arne Sørensen, (Odense: Syddansk Universitetsforlag, 2009), p. 190. 
fully studied through Van Elteren's analytical Americanization framework focusing on transmission, transnationalization, and appropriation.

In his studies of Americanization, Van Eltern understands transmission as processes, such as journalistic practices or new technology, originating in the United States and then transferred to other countries. In the current study, transmission is not just a process, but an object of analysis, whereby the success of American officials in creating a "favorable climate of opinion" amongst Danish journalists may be evaluated and assessed. As it was phrased by the United States Department of State, the object of the cultural diplomacy strategy was stating "the foreign and domestic policies of the United States as persuasively as possible." 16

In order for the American attempt at transmission to have any effect on a receiving country, a "conduit" was needed. In this case, the conduit was journalists on educational exchange, experiencing what Van Elteren calls transnationalization. which he defines as a process occurring in "contact zones," which are areas where "local meanings and practices interact with the intruding beliefs and practices." Danish journalists not only encountered American norms and values when they were on educational exchange to the United States, but also when attending events hosted by the American Embassy in Copenhagen. Based on evaluation reports, American officials argued that these encounters would have an effect on Danish journalists' attitudes towards the United States.

Appropriation is a term which is understood as the "volume ('size' and scale) of ideas, goods, services and practices imported or adopted from the United States, and the extent of their reach."17

In the current study, the extent to which ideas, and journalistic practices, emanating from the United States were appropriated by Danish journalists during educational exchange will be assessed through an analysis of returning journalists' exchange evaluations.

These study tours, as Nils Arne Sørensen and Klaus Petersen note, were important transnational contact zones, where "Danish businesspeople, union leaders, academics and journalists with their own eyes experienced the United States, and where they, according to the plan, brought back in-

16 Willim G. Roll, "USIE Country Papers." p. 3.

17 Mel Van Elteren, Americanism and Americanization: A Critical History of Domestic and Global Influence, pp. $145-178$. 
spiration to modernize Danish society in the American image." ${ }^{18}$ Such trips to the United States were afforded Danish teachers, journalists, politicians, union members, and scholars, believed by representatives at the American Embassy in Copenhagen to be important (future) opinion leaders or agenda setters. ${ }^{19}$

Public Affairs Officer Brooks McClure testified to the importance of educational exchange in 1970 when he emphasized study trips followed by seminars, as "the most effective means to promote a better understanding of the U.S." 20

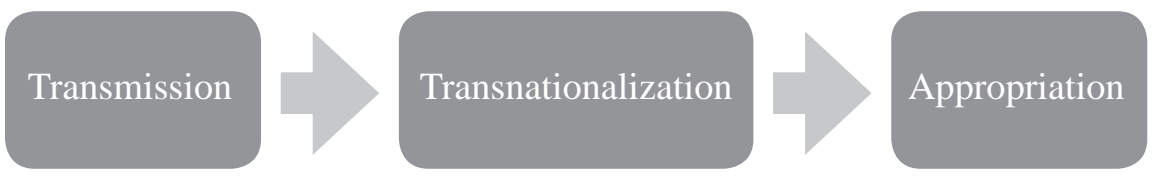

Table 1 - Van Elteren's framework for Americanization: Transmission from the United States, picked up through transnational knowledge exchange and appropriation in the receiving country.

\section{Transmission}

Trips to the United States were only one part of the American diplomatic toolbox, however. From the very beginning of the Cold War, American Embassy officials attempted transmission initiatives such as personal visits with editors, sponsorship of brief journalistic visits to the United States, and publication of material with a favorable perspective on United States policies to influence Danish journalists. These initiatives brought some initial success. As Roll reported back to the Department of State in 1950,

Close liaison exists between the Press Section and Danish journalists, a situation which results in good current coverage on all aspects of American life and the appearance of an

18 Klaus Petersen and Nils Arne Sørensen, "Kommunister, Jan-Bøger Og Drømmekøkkener [Communists, Jan-Books and Dream Kitchens]," Jysk Selskab for Historie, no. 1 (2007), pp. 40-41.

19 Ernest E. Goodman, "Danish Journalist's Impressions as Result of Inter-Agency Journalists Tour," (National Archives. RG 59. General Records of the Department of State. Central Foreign Policy Files, 19671969. Culture and Information. PPB CZECH to PPB FIN. Box 384. May 16, 1969). The abbreviation USIS (United States Information Service) was used by Americans Abroad while USIA (United States Information Agency) was used in the United States to avoid confusion with other abbreviated agencies.

20 Amembassy Copenhagen, (RG 59. General Records of the Department of State. Subject Numeric Files. Culture and Information. EDU. 10-3. DEN1971). 
increasing amount of material throughout Denmark in Danish magazines and newspapers, all of which reflects a better understanding of American motives and viewpoints. ${ }^{21}$

The main conscious effort to Americanize the Danes on the symbolic level was thus organized from the American Embassy where a Public Affairs Officer, Cultural Affairs Officer, and Information Officer directed the efforts. ${ }^{22}$

Yet, the attempt to Americanize Danish journalists during the Cold War occurred in a broader context in which the way the United States was perceived around the world shaped the American Embassy officials' work environment. In the years immediately after World War II, Danes generally had a positive view of the United States, but from an American perspective it became increasingly difficult to state American motives persuasively to Danish journalists in the late 1960s. The American officials' challenges in the 1960s and 1970s stemmed primarily from Danish opposition to the Vietnam War and the struggle over racial inequality within the United States.

But in the years immediately after Denmark joined NATO in 1949, the American delegation enjoyed a fairly "favorable climate of opinion." Through daily news bulletins, periodicals, booklets, library and film events, American Embassy officials "tried to influence Danish State Radio and the Danish press" and well as the larger public. ${ }^{23}$ According to Roll's report, transmission of American ideas in Denmark was very successful in the 1950s, and though it is important to remember, as Richard Pells reminds us, that "the embassies tended to send reports back to Washington proclaiming that every concert, every speaker, and every exchange program had been a smashing success," the American officials in Denmark seemed to make tangible progress during that decade. ${ }^{24}$

As the Danish cultural historian Søren Schou has pointed out, Americans were seen as "the bountiful relatives from abroad," who had a "halo of luxury and wealth" which was inspiring to the Europeans who experienced restrictions on consumer goods during the war. These structural conditions

21 William G. Roll, "USIE Country Papers," p. 4.

22 Marti Jensen, "En Krig På Værdier-Mål Og Midler I Det Amerikanske Kulturdiplomati [a War on Values: Means and Ends in the American Cultural Diplomacy]," pp. 16-17.

23 Nils Arne Sørensen and Klaus Petersen, "Ameri-Danes and Pro-American Anti-Americans"; ibid. pp. 118119. Also William G. Roll, "USIE Report for December, 1949," (National Archives. RG 59. Department of State. Decimal file. 1950-1954. From 511.59/12-650 to 511.59/12-2950. Box 2422. February 14, 1950).

24 Richard Pells, Not Like Us: How Europeans Have Loved, Hated, and Transformed American Culture since World War II, p. 87. 
created an international climate relatively susceptible to influence from the United States in the early post-war years. ${ }^{25}$ Despite the progress through news bulletins and movies, Roll and his successors, however, maintained that educational exchange would be the most effective way to influence the Danes. Leading Danish citizens should ideally experience the United States, and in return American academic and technological knowledge should be shared with European allies. Thus, the interdisciplinary field of American Studies became, "an essential component of Washington cultural diplomacy."26

Some of the most gifted early scholars within the field had personally served in World War II and believed strongly in the ideals upon which the United States was founded, which in turn led to an easily exportable "consensus" view of American society. ${ }^{27}$ Through the writings and visiting lectures of scholars like F.O. Matthiesen, Henry Nash Smith, and Leo Marx, Europeans were told the story of "an essentially holistic, affirmative, nationalistic project primarily aimed at identifying and documenting the distinctive features of the culture and society chiefly created by white European settlers in the territory now comprising the US." ${ }^{28}$

To Danish scholars like Schou, these efforts, coupled with the coverage in Danish media, created "a glorified, but also a very convincing, artistically persuasive image" of the United States in the early 1950s. ${ }^{29}$ As a result, ideas transmitted from the United States through a media intermediary were quite successful and voluntarily appropriated by a large segment of young Danes who grew up in the years bracketing World War II, as Danish academic Jan Gretlund has noted.

To a large extent Danes born in the forties, as I was, were produced by the imported culture. Our cartoons were Donald Duck, Little Orphan Annie, Dick Tracy, and Super-

25 Søren Schou, "Postwar Americanisation and the Revitalisation of European Culture," in Reappraising Transnational Media, ed. Michael Skovmand and Kim Christian Schrøder (London: Routledge, 1992), pp. 146-147.

26 Richard Pells, Not Like Us: How Europeans Have Loved, Hated, and Transformed American Culture since World War II. p. 95.

27 Leo Marx, "On Recovering the 'Ur' Theory of American Studies," American Literary History 17, no. 1 (2005), pp. 119-121. See also Günther Bischoff, "Two Sides of the Coin: The Americanization of Austria and Austrian Anti-Americanism," in The Americanization of Europe, ed. Alexander Stephan (New York: Berghan Books, 2006), pp. 159-161.

28 Leo Marx, "On Recovering the "Ur" Theory of American Studies," pp. 119-121.

29 Søren Schou, "Postwar Americanisation and the Revitalisation of European Culture," p. 147. 
man (...) Things American dominated our childhood and youth and as adults we remain in the ambicultural state where most of the concepts in our consciousness are American imports. $^{30}$

Yet, in the second half of the 1960s the international climate soured somewhat towards United States' foreign and domestic policy, mainly due to the country's involvement in the Vietnam War and the intense struggle over Black Americans' civil rights, which from a foreign perspective seemed at odds with the ideal of equality set forth in the American Charters of Freedom. ${ }^{31}$ Consequently, during the 1960 s the focus within academia in Denmark shifted from the earlier glossed over consensus-view of the United States to attention directed at conflict within the United States.

Discontent with American domestic and foreign policy also had tangible ramifications in Denmark. Few venues served as a better location for antiAmerican protest than the Rebild Festival, an annual gathering held since 1911 on American Independence Day to strengthen the bond between Denmark and the United States. Year after year prominent Americans came to speak and give their latest take on Danish-American relations. Richard M. Nixon came in 1962; Hubert H. Humphrey, Nixon's main rival in the 1968 presidential race, was there in 1969; Michigan governor George Romney visited in 1970; and Ronald Reagan, then governor of California, spoke in 1972.

Many of the Rebild Festivals in the late 1960s and early 1970s attracted anti-American protests. ${ }^{32}$ The theatre group Solvognen received publicity during the bi-centennial of the United States in 1976, when its members staged an illegal "happening" dressed as Native Americans to portray the perceived betrayal of proclaimed American ideals such as freedom, democracy, and justice in the aftermath of the Vietnam War. The police clashed

30 Jan Nordby Gretlund, "The American Within: Danes and American Literature," in As Others Read Us: International Perspectives on American Literatue, ed. Huck Gutman (Amherst: The University of Massachussets Press, 1991), p. 66.

31 Nils Arne Sørensen, "Er Vi Blevet Ameridanere? Om Amerikaniseringsprocesser Gennem 200 År" [Have We Become Ameri-Danes? On Americanization Processes through 200 Years], Historielarerforeningen for Gymnasiet og HF, no. 177 (2008), p. 22.

32 Dudley, Jr. Guilford, “July 4 Celebration in Denmark an Unquestionable Succes,” (National Archives. RG 59. General Records of the Deparment of State. Subject Numeric Files 1970-1973. Culture and Information. CUL-CHILE. Box 369. July 12, 1972). Dudley in his report noted that, "for the first time in five years, there were no anti-Vietnam demonstrations." 
with the demonstrators and the images were broadcast on national television in Denmark and even in the United States. ${ }^{33}$

The adverse international climate and negative media coverage challenged the officials at the American Embassy. The United States Information Service employees in Copenhagen therefore tried to remedy the situation through different initiatives directed at Danish journalists. First, the American Embassy helped facilitate free trips to the United States. Second, the Embassy officials worked to cultivate personal relationships with the journalists through one-on-one or two-on-one meetings, and lastly they provided help with setting up interviews for the Danish journalists that were already in the United States.

All these measures led to hopes and expectations from an American perspective that Danish journalists would appreciate the assistance and write in a "balanced manner" about the United States. Yet, in the late 1960s and early 1970s it remained hard to explain American motives to critical Danish journalists who only had brief encounters with the United States. Greater educational exchange opportunities were thought to be the answer, but how did these exchange programs come about and what were their potential effects ? $^{34}$

Public Law 402, also known as the 1948 Smith-Mundt Act provided an important starting point for exchange between Denmark and the United States. For the first time the American government made an "exchange of persons program" permanent and enabled the American Embassy along with its Danish allies to facilitate these exchanges as soon as possible. Working closely together with private organizations such as the AmericanScandinavian Foundation, the Danish-American Society, and the Danish International Student Committee, the American Embassy in Copenhagen sent close to 500 Danish students to the United States in 1949. ${ }^{35}$

$[\mathrm{N}]$ umerous conferences and interviews were held with Danish authorities in the various fields covered by the categories of the grants. [...] Applications and recommendations were likewise submitted by the Embassy after carefully screening the applicants, in the case of leaders in the fields of labor, journalism and youth work. ${ }^{36}$

33 Nils Arne Sørensen, ”Fyrre Indianere På Smukke Hesterygge" [Forty Indians on Beautiful Horsebacks], 2009, no. June (2009), http://www.sdu.dk/ /media/Files/Om_SDU/Institutter/ Ihks/Projekter/Amerikansk\%20paa\%20dansk/m_ARTIKEL/Fyrre_indianere.ashx. Page 1. Accessed December 28, 2010.

34 Ernest E. Goodman, ”Danish Journalist's Impressions as Result of Inter-Agency Journalists Tour."

35 William G. Roll, "USIE Country Papers," pp. 5-7.

36 "USIE Report for January and February, 1950" (National Archives. RG 59. Department of State. Decimal file. 1950-1954. From 511.59/12-650 to 511.59/12-2950. Box 2422. April 5, 1950), p. 2. 
From the beginning, the officials at the American Embassy in Copenhagen considered young Danish journalists, and future opinion leaders from other fields, important in fulfilling their mission of stating "the foreign and domestic policies of the United States as persuasively as possible." ${ }^{37}$

Previous to the Smith-Mundt Act, exchange between Denmark and the United States had been sponsored by private organizations such as the Denmark-America Foundation of 1914 with the aim to "further endeavors for practical and cultural co-operation between Denmark and the United States, hereunder especially support Danish citizens' educational exchange in the United States," 38 and after World War II many more transnationally oriented organizations followed.

Roll was happy to report in July 1951 that there was an increase in "privately and government-sponsored exchange activities between the two nations," and added that for the first time in its history, "The Tuborg Foundation has made funds available for study trips to the United States." ${ }^{39}$ A few months later another avenue for cultural exchange opened. In August 1951, Denmark and the United States reached an agreement to establish a Fulbright program in Denmark and the news was very well received in the Danish press. Even Information which, according to American officials, often took a critical stance towards initiatives from the United States, wrote a positive editorial on the prospect of increased inter-cultural exchange and the opportunity to learn more about a powerful ally.

The significance is obvious both for academic requirements and for the international understanding (...) Cultural cooperation with America is more significant presently than ever before since America plays such an overwhelming role in the world. ${ }^{40}$

These positive feelings towards educational exchange were shared by both private and public organizations across the Atlantic. While the United States government initiated both PL 402 and the Fulbright Program during years in which a positive international climate prevailed, private business stepped

37 "USIE Country Papers." p. 3.

38 "Danmark-Amerika Fondet, "Danmark-Amerika Fondet Årsberetning 1994" [the Denmark-America Foundation Annual Report 1994], (Copenhagen, 1994), p. 5.

39 William G. Roll, "Semi-Annual Evaluation Report for USIE - Covering Period from December 1, 1950, to May 31, 1951.," (National Archives. RG 59. Department of State. Decimal file. 1950-1954. From 511.59/12-650 to 511.59/12-2950. Box 2422. July 17, 1951).

40 "Dansk-Amerikansk" [Danish-American], Information, August 24, 1951, p. 2. 
forward as the United States got increasingly involved in its internal civil right struggle and the war in Vietnam.

Ford Motor Company Fund, IBM, Standard Oil, and Readers Digest helped sponsor the World Press Institute which was established in 1961. Over the years WPI awarded scholarships to more than 500 international journalists, among these several Danes, in the hope, from WPI's perspective, that such an exchange could ensure that

International opinion about the United States is shaped by journalists writing from a comprehensive personal background of experience in America. The Institute seeks to achieve this by providing young foreign journalists with an open and unfettered view of American society at every level so that they may return home with new-found ability to report and interpret U.S. affairs more accurately and with deeper understanding. ${ }^{41}$

The mission statement above was found in a pamphlet published in 1971 which accompanied a letter from Assistant Director Mark Peacock to Secretary of State William P. Rogers requesting an interview for the foreign WPI journalists on exchange. According to the letter, WPI officials thought that coverage was biased against the United States and wanted to swing the journalistic pendulum the other way. In the letter Peacock stated the goals of the WPI even more succinctly as he wrote,

The professional international journalists of the World Press Institute will be in Washington February 14 through March 6, 1972. During our visit, our interviews will strive to further the World Press Institute goals of improving the accuracy and fairness of the foreign press reporting about the United States. ${ }^{42}$

Again, exchange initiatives from the United States were deliberately established to promote a positive view of the country through the foreign journalists invited, but foreign journalists did not always agree with the interpretations presented to them by American officials, in some cases with good reason. According to investigative reporting by The New York Times, the United States also engaged in covert propaganda in order to influence

41 ”World Press Institute Fellows 1971-1972,” ed. World Press Institute (RG 59. General Records of the Department of State. Subject Numeric Files, 1970-73. Administration. PR International Commerce 1/1/70 - PR 11/3 5/20/73. Box 273., 1971).

42 Mark Peacock, "World Press Institute," (RG 59. General Records of the Department of State. Subject Numeric Files, 1970-73. Administration. PR International Commerce 1/1/70 - PR 11/3 5/20/73. Box 273. December 20, 1971). 
media coverage in foreign countries. The CIA had "assets" all across the world "throughout the 1950's and 1960's, when the agency's propaganda network was at peak strength." During these years an estimated 800 "propaganda assets," 43 consisting of mostly foreign journalists, were used by the agency, according to The New York Times.

We 'had' at least one newspaper in every foreign capital at any given time, one C.I.A. man said, and those that the agency did not own outright or subsidize heavily it infiltrated with paid agents or staff officers who could have stories printed that were useful to the agency and not print those it found detrimental. ${ }^{44}$

According to The New York Times exposé, even the national Danish news agency Ritzau's Bureau had been infiltrated, but no other documents have yet been uncovered to support this claim. However, even without knowledge of potential covert American efforts, the line between education and propaganda could at times seem blurry to Danish journalists. But much depended on the broader context in which the educational exchange took place. Outside of the 1960s and early 1970s, most journalistic exchanges created greater understanding of American policy, in the eyes of both sponsors and recipients.

\section{Transnationalization}

The American Embassy, DAF, and the Fulbright Commission worked very consciously to select talented men and women who were thought to play a prominent part in Danish society now or later. ${ }^{45}$ To help cultivate future opinion-makers, the American Embassy each year gave out "leader grants" to promising young Danes. ${ }^{46}$ This conscious selection of candidates took place across Europe, and as Günther Bischoff has shown in the case of Austria, American officials were extremely adept at picking the right candidates through a thorough application process, not least in the field of journalism. ${ }^{47}$

43 John M. Crewdson and Joseph B. Treaster, "The CIA's 3-Decade Effort to Mold the World's Views," The New York Times, December 25, 1977. pp. 1 and 12.

44 "Worldwide Propaganda Network Built by the C.I.A.," The New York Times, December 26, 1977.

45 Martin Kryhl Jensen, ’En Krig På Værdier - Mål Og Midler I Det Amerikanske Kulturdiplomati” [A War on Values: Means and Ends in the American Cultural Diplomacy], p. 19.

46 Ibid., p. 13. See also Dean, "Annual Policy Assessment."

47 Günther Bischoff, "Two Sides of the Coin: The Americanization of Austria and Austrian Anti-Americanism." pp. 155-158. 
In 1986, for instance, the American Embassy compiled a list of "Prominent Fulbrighters," where journalists were amply represented. ${ }^{48}$ Among the 21 names appearing on Public Affairs Officer G. J. Kallas' list were Professor Isi Foighel, Attorney General Per Lindegaard, and Member of Parliament Ole Espersen; seven, however, worked, at least part time, as journalists; and an eighth, Bo Green Jensen, listed as "poet," ended up working for the prestigious weekly newspaper Weekendavisen. No other profession had more than two names represented on the list. ${ }^{49}$

The American Embassy played a significant role in the selection of candidates who would later hold prominent positions in Danish society and also evaluated the exchange regularly. Yet, even with the very conscious selection of candidates, American Embassy officials encountered less "successful" educational exchange experiences.

Among the Danish journalists who were invited on a shorter sponsored trip to the United States was Information's Frank Osvald. Osvald was selected for a "European Journalists Tour" to the United States in 1969, but the generosity of the American Embassy officials unexpectedly did not translate into positive coverage. The Danish journalist subsequently published two critical articles on American society, "California's Frustrated Freedom Movement" and "New U.S. Militarism and Isolationism." In these articles Osvald, according to Public Affairs Officer Ernest Goodman, gave "what he calls an analysis" of the cultural and political climate in the United States. Osvald had written on "negro rebellion," as well as the "black panthers, the John Birch Society and Ronald Reagan, of the student rebellion at Berkeley and San Francisco State College, and of the supposed repressive measures being planned to maintain law and order on the campuses." With Danish press coverage such as Osvald's, Goodman felt that he had to explain the reason for the Danish reporter's educational opportunity when he submitted his subsequent report. ${ }^{50}$

Writing confidentially to the United States Information Agency in Washington, Goodman pointed out that he and the Information Officer had a "lengthy discussion with Osvald upon his return to Denmark," and based on the meeting Goodman deemed Osvald "a highly intelligent, though idealis-

48 G. J. Kallas, ’Prominent Fulbrighters," (Rigsarkivet. 10754. Danmark-Amerika Fondet og Fullb. K. 19461988. Korrespondance. 1972-1988. Box 153. March 18, 1986).

49 Ibid.

50 Ernest E. Goodman, "Danish Journalist's Impressions as Result of Inter-Agency Journalists Tour." 
tic, journalist" and elaborated on the differences between his and Osvald's understanding of journalism.

In the course of a detailed examination of his experiences and analysis of his two published stories, Osvald became irritated and offended. He conceded that his writing was not "balanced" from our point of view and acknowledged that sensational and dramatic events were emphasized ("all revolutions are started by small minorities"). He then accepted the point of view that U.S. officials were naturally concerned about a "balanced" view which showed that the national society was not about to fly apart, and, indeed, was achieving some extraordinary if non-violent results. The meeting ended cordially, with another arranged. ${ }^{51}$

As the example of Osvald indicates, a brief visit to the United States did not necessarily translate into a positive view or positive coverage of American society. However, Goodman ended his report on a positive note with the belief that it was still possible to change the attitudes of Danish journalists. "It is felt," he wrote, "that although Osvald is critical of the U.S. at this time, he may reflect upon his experiences there as time goes on, and eventually view the country in a different light." 52

Nevertheless, in the context of the Vietnam War and the domestic problems described in Osvald's articles this proved difficult. In 1971, the American Embassy recommended Politiken's Kaare Toftkær Jensen as a participant in an "Inter-Agency journalist's tour" to the United States. The objective was to give the journalists first-hand experience with American society, and the embassy in Copenhagen provided research material before the trip. The embassy officials therefore hoped that Jensen would use this information to write "balanced" stories, but subsequently concluded that "the result, at least the initial reaction, has been disappointing." 53

Yet, Osvald and Toftkær Jensen had not been in the United States on extended exchange, and for those Danish journalists who were afforded longer periods of time abroad, the educational exchange seems to have indirectly shaped a more positive view of the United States. It cannot be inferred from the evaluation reports, however, whether or not this greater understanding of the United States was transferred to the editorial meeting rooms and thus to the broader public through media content.

53 Bruce McClure, "Inter-Agency Journalists Tour," (RG 59. General Records of the Department of State. Subject Numeric Files 1970-1973. Culture and Information. PPB 9 - Chinat 1/1/70 thru PPB 9 - EGY 2/1/72. Box 427, 1970). 
However for the first Danish journalist at Columbia University's Advanced International Reporting Program, there was no doubt that educational exchange to the United States helped him become a more knowledgeable reporter on American issues. Boelsgaard came to the prestigious journalism school through a grant from "Thanks to Scandinavia," in 1969 and described himself as a "kid in a chocolate store," when he saw the course catalogue. ${ }^{54}$

Though Boelsgaard did not address Columbia University's direct impact on his subsequent writings about the United States, his positive assessment was shared by most Danes who enjoyed a lengthy exchange experience regardless of their field of study. ${ }^{55}$ Professor Isi Foighel, who conducted research during a stay at Harvard Law School in 1969 and subsequently attended several seminars on American politics in Denmark, wrote of his experience.

It is beyond any doubt that my opinion of American life has changed during my visit. It makes a great difference to live in a country for six months to get some idea of the size of the country and of the problems which are debated in the American society. I could not say that the information I, until my stay in the US, had received was inaccurate but it is of course a quite different thing to read about a country and to live in it. ${ }^{56}$

With evaluations like these flowing in from all over the United States, the American Embassy's hunch that exchange was the most effective approach to the Danes was strengthened. The positive view of educational exchange presented by doctors and academics were shared by journalists like Boelsgaard who subsequently noted that there was also much to absorb from the United States in terms of higher learning. "The Americans are significantly further along with journalistic education than we are in Europe," concluded Boelsgaard. ${ }^{57}$

What separated the above evaluations from those of Osvald, among others, was primarily the length of stay in the United States, but attitudes towards the powerful NATO ally also seem to be even less critical after the end of the Vietnam War. While individual experiences among prominent

54 Kurt Boelsgaard, "Sabbatår Med Ekstra Slid [Sabbatical with Extra Work],” Journalisten, no. 9 (1970), p. 11.

55 Ibid., p. 11.

56 Isi Foighel, "Report of Visiting Scholar," (Rigsarkivet. 10754. Danmark-Amerika Fondet og Fullb. K. 1956-1981 DK Legatmodtagere, Rapporter/Evalueringer 1970-1981. Box 77. October 20, 1969).

57 Boelsgaard, "Sabbatår Med Ekstra Slid [Sabbatical with Extra Work]," p. 11. 
journalists in the 1980s and 1990s varied to an extent, some things also stayed the same. Without exception the written evaluations available from journalists sponsored by the Denmark-America Foundation or the Fulbright Program mention the unique aspect of their experience and their greater understanding of American society.

When Samuel Rachlin, who later became one of Denmark's most famous television anchors, in 1985 wrote about his experience at Harvard University, he noted that his exchange year had "exceeded all expectations regarding an intense and stimulating stay in an American university environment" and added that "the year at Harvard opened my eyes to America and the Americans and I discovered and understood more of the country and the people than before both good and bad." 58

In 1991 Ulrik Haagerup, who later became head of the news division at the Danish Broadcast Service (DR), an equivalent of the American NBC, expressed a similar opinion. Haagerup had spent a year at Stanford University as a John S. Knight Fellow and emphasized the knowledge gained from the group of talented journalistic peers. ${ }^{59}$

The hectic pace of a university stay in the United States, the greater knowledge of American society, and the development of a tight-knit network are also apparent in Anders Krab-Johansen's evaluation of his year at Columbia's Graduate School of Journalism in 1994. Krab-Johansen later became editor-in-chief of B $\phi$ rsen, the Danish equivalent of The Wall Street Journal, and called his nine months in New York "the most intense I have yet experienced." Throughout the year, Krab-Johansen noted with a sense of admiration that he had been guided in his studies by an advisor who was a former journalist from The New York Times. ${ }^{60}$

The experiences expressed by Rachlin, Haagerup, and Krab-Johansen were echoed by several Danish journalists in the subsequent years. The overall message was the same: Six months to a year at an American university was an intense experience with great opportunities to network with fellow journalists; it was extremely fruitful in terms of a deeper understand-

58 Samuel Rachlin, "Om at Opdage Harvard [Discovering Harvard]," ed. Danmark-Amerika Fondet (Copenhagen: Danmark-Amerika Fondet Annual Report, 1985), pp. 12-13. Rachlin had previously been a graduate student, as well as a Fulbright recipient, at Columbia School of Journalism in 1977.

59 Ulrik Haagerup, ’Frit Valg På Stanfords Hylder [A Kid in Stanford's Candy Store]," ed. Danmark-Amerika Fondet (Copenhagen: Danmark-Amerika Fondet Annual Report, 1991).

60 Anders Krab-Johansen, "Stress Og Jag Fra Første Dag [Hustle and Bustle from Day One]," ed. DanmarkAmerika Fondet (Copenhagen: Danmark-Amerika Fondet Annual Report, 1994), pp. 16-18. 
ing of international relations, and in most instances, especially for younger reporters, journalistic practices and methodologies were also impacted. ${ }^{61}$

\section{Appropriation}

Though it is difficult to gauge whether the newfound knowledge was implemented in every-day journalistic practice, a recent example from Journalisten, the periodical of the Danish Union of Journalists, does indicate that it was. After his exchange at Columbia University Graduate School of Journalism, Krab-Johansen worked his way up to become the political editor of Politiken in 2008. According to Journalisten, Krab-Johansen had adopted the American philosophy of writing politically neutral news stories. ${ }^{62} \mathrm{Krab}$ Johansen's own evaluation of the educational exchange 16 years later sheds some light on the formative nature of a stay at one of the elite American journalism schools.

There is no doubt that my year at Columbia School of Journalism has meant everything to the way I approach journalism. (...) [It was] inspiring to be taught by professors who had worked at The New York Times, Wall Street Journal, CBS News and other worldrenowned media and be coached by journalists who had won a Pulitzer Prize. The standards for quality grew to be fairly high and my respect for the profession undoubtedly increased. ${ }^{63}$

To Danish journalists like Rachlin and Haagerup it seems, however, that the influence from the United States had a more indirect impact on their journalistic practices. Neither wrote about their increased knowledge of the United States being transferred into ideas at editorial meetings. This does not mean that it did not happen, but based on what these two prominent journalists wrote, they gained a more nuanced knowledge about the United States and an expanded network within their field. Working from the cited evaluations it seems safe to conclude that American officials achieved the goal of providing young foreign journalists with a more accurate and deeper understanding of U.S. affairs through educational exchange.

61 Sarah Holm Johansen, 'Indtryk Fra Legatmodtagere [Impressions from Grant Recipients],' ed. DanmarkAmerika Fondet (Danmark-Amerika Fondet Annual Report, 2007), p. 21.

62 Signe Højgaard Nielsen and Mathias Bencke Fremmen, "Da Mr. News Fik Nok Af Views [When Mr. News Became Fed up with Views]," Journalisten, March 24, 2010. p. 9.

63 Anders Krab-Johansen, E-mail to author regarding stay at Columbia University, December 15, 2010. 
Whether this deeper understanding also translated into persuasively stating foreign and domestic policy as was the explicit aim of the United States Department of State seems less clear. Additionally, there is no evidence in the evaluation reports that the implicit World Press Institute and State Department aim of improving accuracy and fairness in foreign reporting was achieved directly through educational exchange. More studies are needed to assess whether these educational exchanges had an indirect impact on journalists' reporting.

Interviews with former Fulbright scholars in the Danish media combined with content analyses of journalistic output before and after a lengthy exchange experience in the United States could be a fruitful way forward to shed some light on this important question.

\section{Conclusion}

This article has shown that Danish journalists educational exchange in the United States, from the late 1940s and forward, was seen by the American State Department as the most important way to influence attitudes towards the United States. The educational exchange facilitated through the Fulbright Commission and other American organizations, such as the World Press Institute, was thus part of a conscious strategy in order to gain an upper hand in the cultural Cold War.

The cultural diplomatic object from an American standpoint was stating "the foreign and domestic policies of the United States a persuasively as possible." Based on this study the Americans partly succeeded with educational exchange but the success was seemingly dependent on the length of the educational exchange as well as the broader societal context within which the exchange took place.

In the 1950s, American officials ostensibly had an easier time stating the policies of the United States persuasively. However, in the late 1960s and early 1970s, during a low point in international opinion on the United States, it was difficult for American officials to influence journalists from left-leaning news outlets such as Information and Politiken also through short trips to the United States.

Nevertheless, for those who came to the United States after the end of the Vietnam War and spent a longer period of time in the United States, the experience was almost uniformly positive. In the 1980s and 1990s a host of prominent Danish journalists went on educational exchange to the 
United States, and the overall picture gleaned from the exchanged Danish journalists' evaluations is one of a very fruitful year in terms of knowledge acquisition, changed impression of the United States, networking, and greater understanding of different media environments. It can therefore be concluded that American officials achieved the goal of providing young foreign journalists with a more accurate and deeper understanding of U.S. affairs through educational exchange.

Exactly how these nuanced attitudes carried over into daily journalism routines is difficult to ascertain, but the example of Krab-Johansen shows that an educational exchange at an elite American journalism school could have lasting effects on journalistic practice. More studies are needed, however, to analyze the effects of the transnational exchanges on actual news content and the decisions being made before stories are published.

\section{Bibliography}

Bischoff, Günther. "Two Sides of the Coin: The Americanization of Austria and Austrian Anti-Americanism." In The Americanization of Europe, edited by Alexander Stephan. New York: Berghan Books, 2006.

Boelsgaard, Kurt. "Sabbatår Med Ekstra Slid [Sabbatical with Extra Work]." Journalisten, no. 9 (1970).

Bourdieu, Pierre. On Television. Translated by Priscilla Parkhurst Ferguson. New York: The New Press, 1998.

Copenhagen, Amembassy. National Archives. RG 59. General Records of the Department of State. Subject Numeric Files. Culture and Information. EDU. 10-3. DEN, 1971.

Crewdson, John M., and Joseph B. Treaster. "The Cia's 3-Decade Effort to Mold the World's Views." The New York Times, December 25, 1977.

—. "Worldwide Propaganda Network Built by the C.I.A." The New York Times, December 26, 1977, 1.

Dean, John Gunther. "Annual Policy Assessment." http://aad.archives.gov/aad/createpdf?rid $=84211 \& \mathrm{dt}=2082 \& \mathrm{dl}=1345$. April 29, 1976.

Elteren, Mel Van. Americanism and Americanization: A Critical History of Domestic and Global Influence. Jefferson, North Carolina: McFarland \& Company, Inc., Publishers, 2006.

—. "Rethinking Americanization Abroad: Toward a Critical Alternative to Prevailing Paradigms." The Journal of American Culture 29, no. 3 (2006).

Foighel, Isi. "Report of Visiting Scholar.” Rigsarkivet. 10754. Danmark-Amerika Fondet og Fullb. K. 1956-1981 DK Legatmodtagere, Rapporter/Evalueringer 1970-1981. Box 77. October 20, 1969.

Fondet, Danmark-Amerika. "Danmark-Amerika Fondet Årsberetning 1994 [the DenmarkAmerica Foundation Annual Report 1994].” Copenhagen, 1994.

Goodman, Ernest E. "Danish Journalists' Impressions as Result of Inter-Agency Journalists Tour." National Archives. RG 59. General Records of the Department of State. Central 
American Studies in Scandinavia, 44:2

Foreign Policy Files, 1967-1969. Culture and Information . PPB CZECH to PPB FIN. Box 384. May 16, 1969.

Gretlund, Jan. "The American Within: Danes and American Literature." In As Others Read Us: International Perspectives on American Literatue, edited by Huck Gutman. Amherst: The University of Massachussets Press, 1991.

Guilford Dudley, Jr. "July 4 Celebration in Denmark an Unquestionable Succes." National Archives. RG 59. General Records of the Deparment of State. Subject Numeric Files 1970-1973. Culture and Information. CUL - CHILE. Box 369. July 12, 1972.

Haagerup, Ulrik. "Frit Valg På Stanfords Hylder [a Kid in Stanford's Candy Store].” edited by Danmark-Amerika Fondet. Copenhagen: Danmark-Amerika Fondet Annual Report, 1991.

Jensen, Martin Kryhl. "En Krig På Værdier - Mål Og Midler I Det Amerikanske Kulturdiplomati [a War on Values: Means and Ends in the American Cultural Diplomacy]." In Fodnoter, edited by Bent Jensen. Copenhagen: Center for Koldkrigsforskning, 2009.

Johansen, Sarah Holm. "Indtryk Fra Legatmodtagere [Impressions from Grant Recepients]." edited by Danmark-Amerika Fondet: Danmark-Amerika Fondet Annual Report, 2007.

Kallas, G. J. "Prominent Fulbrighters.” Rigsarkivet. 10754. Danmark-Amerika Fondet og Fullb. K. 1946-1988. Korrespondance. 1972-1988. Box 153. March 18, 1986.

Krab-Johansen, Anders. "Stress Og Jag Fra Første Dag [Hustle and Bustle from Day One]." edited by Danmark-Amerika Fondet. Copenhagen: Danmark-Amerika Fondet Annual Report, 1994.

—. E-mail to author regarding stay at Columbia University, December 15, 2010.

Kuisel, Richard. "Debating Americanization: The Case of France." In Global America? The Cultural Consequences of Globalization, edited by Ulrich Beck, Natan Sznaider and Rainer Winter. Liverpool: Liverpool University Press, 2003.

Marx, Leo. "On Recovering the "Ur" Theory of American Studies." American Literary History 17 , no. 1 (2005).

McClure, Bruce. "Inter-Agency Journalists Tour." National Archives. RG 59. General Records of the Department of State. Subject Numeric Files, 1970-1973. Culture and Information. PPB 9 - Chinat 1/1/79 through PPB - EGY 2/2/72. Box 427, 1970. , 1970

n. "Dansk-Amerikansk [Danish-American]." Information, August 24, 1951.

Nielsen, Signe Højgaard, and Mathias Bencke Fremmen. "Da Mr. News Fik Nok Af Views [When Mr. News Became Fed up with Views].” Journalisten, March 24, 2010.

Peacock, Mark. "World Press Institute." National Archives. RG 59. General Records of the Department of State. Subject Numeric Files, 1970-73. Administration. PR International Commerce 1/1/70 - PR 11/3 5/20/73. Box 273. December 20, 1971.

Pells, Richard. Not Like Us: How Europeans Have Loved, Hated, and Transformed American Culture since World War II. New York: Basic Books, 1997.

Petersen, Klaus, and Nils Arne Sørensen. "Kommunister, Jan-Bøger Og Drømmekøkkener [Communists, Jan-Books and Dream Kitchens]." Jysk Selskab for Historie, no. 1 (2007): $27-48$.

Rachlin, Samuel. "Om at Opdage Harvard [Discovering Harvard].” edited by DanmarkAmerika Fondet. Copenhagen: Danmark-Amerika Fondet Annual Report, 1985.

Roll, William G. "Semi-Annual Evaluation Report for USIE - Covering Period from December 1, 1950, to May 31, 1951.”: National Archives. RG 59. Department of State. Decimal file. 1950-1954. From 511.59/12-650 to 511.59/12-2950. Box 2422. July 17, 1951.

—. "USIE Country Papers." National Archives. RG 59. Department of State. Decimal file. 1950-1954. From 511.59/12-650 to 511.59/12-2950. Box 2422. May 2, 1950.

—. "USIE Report for December, 1949." National Archives. RG 59. Department of State. 
Decimal file. 1950-1954. From 511.59/12-650 to 511.59/12-2950. Box 2422. February 14, 1950.

—. "USIE Report for January and February, 1950." National Archives. RG 59. Department of State. Decimal file. 1950-1954. From 511.59/12-650 to 511.59/12-2950. Box 2422. April 5, 1950.

Schiller, Herbert I. Communication and Cultural Domination. New York: International Arts and Sciences Press, 1976.

Schou, Søren. "Postwar Americanisation and the Revitalisation of European Culture." In Reappraising Transnational Media, edited by Michael Skovmand and Kim Christian Schrøder. London: Routledge, 1992.

Stephan, Alexander. "Cold War Alliances and the Emergence of Transatlantic Competition: An Introduction." In The Americanization of Europe: Culture, Diplomacy, and Anti-Americanism after 1945, edited by Alexander Stephan. New York: Berghahn Books, 2006.

Sørensen, Nils Arne. "Er Vi Blevet Ameridanere? Om Amerikaniseringsprocesser Gennem 200 År [Have We Become Ameri-Danes? On Americanization Processes through 200 Years]." Historielarerforeningen for Gymnasiet og HF, no. 177 (2008): 19-25.

—. "Fyrre Indianere På Smukke Hesterygge [Forty Indians on Beautiful Horsebacks]." 2009, no. June (2009). http://www.sdu.dk/ /media/Files/Om_SDU/ Institutter/Ihks/Projekter/Amerikansk\%20paa\%20dansk/m_ARTIKEL/Fyrre_indianere.ashx.

—. "Kulturmøder, Selvkolonisering Og Imperialisme Om Usamerikaniseringen Af Europa [Cultural Encounters, Self-Colonialization and Imperialism: About Usamericanization of Europe]." In Transnationale Historier, edited by Anne Magnussen Sissel Bjerrum Fossat, Klaus Petersen, Nils Arne Sørensen,. Odense: Syddansk Universitetsforlag, 2009.

Sørensen, Nils Arne, and Klaus Petersen. "Ameri-Danes and Pro-American Anti-Americans." In The Americanization of Europe: Culture, Diplomacy, and Anti-Americanism after 1945, edited by Alexander Stephan. New York: Berghahn Books, 2006.

Villaume, Paul. Allieret Med Forbehold: Danmark, Nato Og Den Kolde Krig [Allied with Reservations: Denmark, Nato and the Cold War]. Copenhagen: Eirene, 1995.

"World Press Institute Fellows 1971-1972." edited by World Press Institute: National Archives. RG 59. General Records of the Department of State. Subject Numeric Files, 1970-73. Administration. PR International Commerce 1/1/70 - PR 11/3 5/20/73. Box 273., 1971. 